is not referring to a copy of the Sicilian temple or to a replica of its cult statue, but rather that he is underlining the continuation of ritual practices peculiar to that model and retained only in the sanctuary outside the pomerium.

Scuola Normale Superiore, Pisa

ANNA ANGUISSOLA

a.anguissola@sns.it

doi:10.1017/S0009838806000747

\title{
A TEXTUAL NOTE ON XENOPHON OF EPHESUS 3.9.4
}

In Xenophon's Ephesian Tale the male hero Habrocomes is at 3.9 once again in quest of his beloved Anthia. He has allied himself with the brigand Hippothous and eventually arrives with him and his band of robbers somewhere near the shore of Cilicia. After a fruitless excursion Habrocomes returns tired. Meanwhile Hippothous' men have prepared dinner. Habrocomes, however, is too depressed to join them and decides to rest. The following passage about the robbers' $\delta \epsilon \hat{\imath} \pi \nu \nu \nu$ contains a

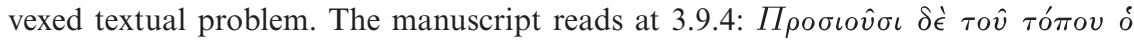

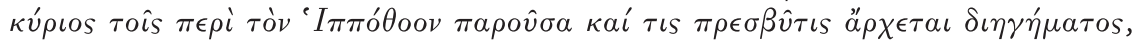

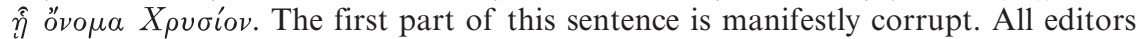
made emendations in one way or another. I shall consider here only the three major ones:

1. Hercher wrote in his Teubneriana of Erotici Scriptores Graeci (1858-9):

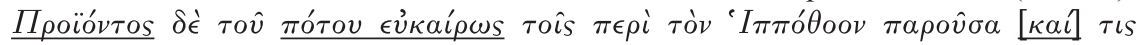

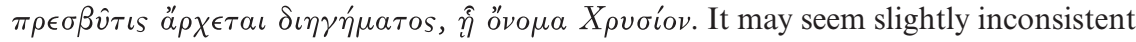
to speak of a 'continuation of drinking' even though drinking was not mentioned before. However, taking pleasure in a symposium after dinner is the normal course of events in a Greek banquet, and there is a close parallel for skipping the transition

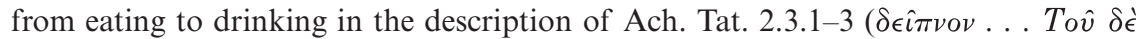
$\left.\pi o ́ \tau o v \pi \rho o{ }^{\prime} o ́ v \tau o s\right){ }^{1}$

2. In the Budé-edition of 1926 Dalmeyda proposed:

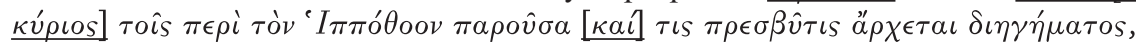

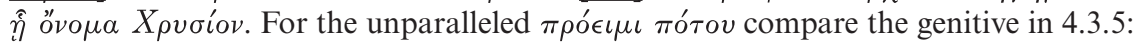

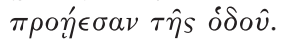

3. Papanikolaou rejects in his Teubneriana of 1973 the former suggestions for two reasons: ${ }^{2}$ first, he doubts the possibility of a longer symposium in absence of the protagonist Habrocomes; second, he disapproves of the fact that earlier editors neglected the manuscript tradition to such an extent. His own reading is indeed very

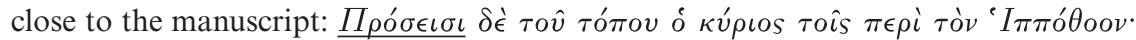

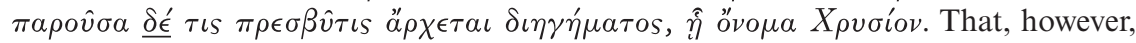
makes no good sense. A host ( $\kappa$ v́pıs), with whom the men stay, is neither mentioned before nor does he appear afterwards. His entrance adds nothing to the story and

${ }^{1}$ Cf. P. Schmitt-Pantel, La cité au banquet: histoire des repas publics dans les cités grecques

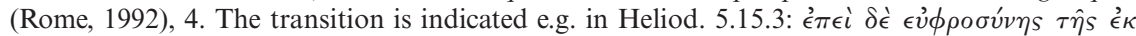

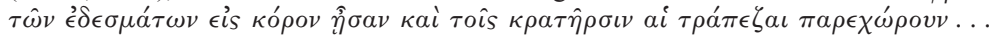

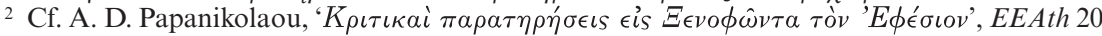
(1969-70), 360 . 
would be completely unmotivated. Papanikolaou blames this on the assumed epitomator, which is not very persuasive. There is no parallel in which the epitomator-provided that there was one-would have operated in such a crude manner. The second objection is not valid either: in fact Habrocomes does not disappear for long; he hears what is going on and reacts, albeit with some delay (3.9.7). The narrator did not forget him. Besides, the drunkenness of Hippothous'

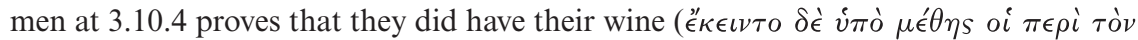
' $I \pi \pi o ́(\theta o v)$.

Papanikolaou's emendation was praised by G. Nachtergael without any supporting arguments. T. Hägg, however, subjected it to harsh criticism. ${ }^{3}$ On the whole, Hägg's opinion was shared by J. N. O'Sullivan, the editor of a forthcoming new Teubner text, who rejected in 1986 Papanikolaou's solution and defended the earlier conjecture of Dalmeyda. ${ }^{4}$ But Papanikolaou was probably right about Hercher's and Dalmeyda's neglect of the manuscript text. Therefore I should like to make a suggestion which

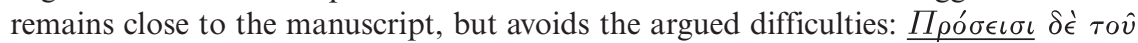

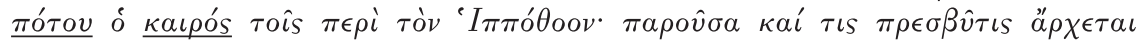

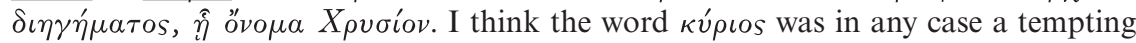
reading for a Byzantine scribe. An alternative or supplementary explication for the erroneous replacement of каıрós by кúpıos could be the fact that these words were sometimes collocated in puns. ${ }^{5}$ The restitution of kaıpós is much less radical than eliminating the word completely (Dalmeyda) or marginalizing it as an adverb (Hägg).

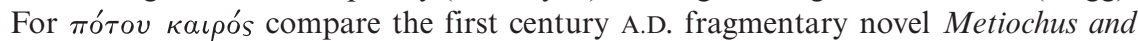

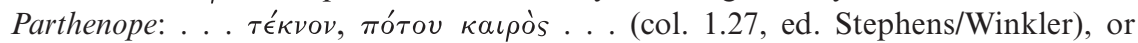
Garnaud's reading of Ach. Tat. 2.9.1 in his Budé-text (according to POxy. 1250, third

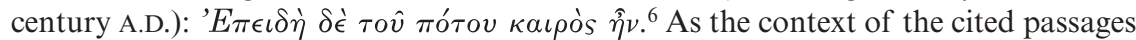
shows, the expression tó symposium with the various entertainment connected to it. This accords well with Xenophon's description: after dining, the robbers are about to start their symposium and listen to Chrysion's story for their amusement (a narrative variation of the theme of symposiastic poetry and philosophy). As far as I can see, there is no verbatim

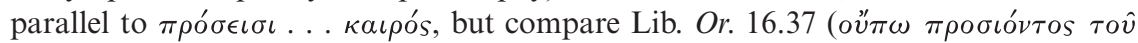

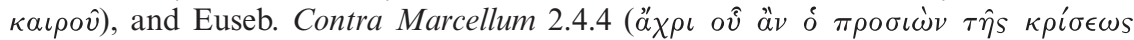

3 Cf. Nachtergael in Scriptorium 30 (1976), 136; Hägg's considerations in Gnomon 49 (1977), 461 are worth citing: 'P.s Versuch, diese korrupte Passage herzustellen, ist denen seiner Vorgänger

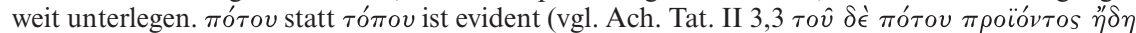

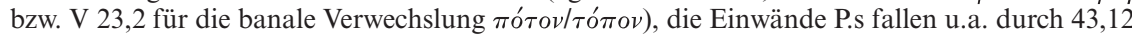
ímò $\mu \epsilon^{\prime} \theta \eta s$ weg. Das unmögliche ó $\kappa u ́ p \iota s$ durch einen Hinweis auf die vermeintliche Epitomierung zu verteidigen, ist ein billiger Ausweg (vermutlich steckt hinter ó $\kappa u ́ p \iota s$ [oder $O K \Sigma$ ?] ein Adverb, wie $\eta \delta \eta$ bei Ach. Tat.). Die neue Interpunktion ... ist deshalb abzulehnen und каi "auch" beizubehalten.'

4 J. N. O'Sullivan, 'Notes on Xenophon of Ephesus Books III and IV', RhM 129 (1986), 83. O’Sullivan's new Teubneriana had not yet appeared when this note was written.

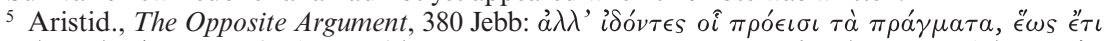

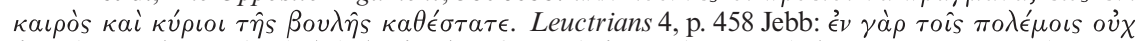

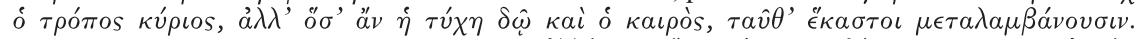

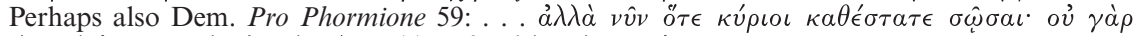

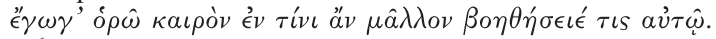

6 In addition to that, cf. the twelfth-century novel Hysmine et Hysminias by Eustathius Macrembolites: $\pi$ ó

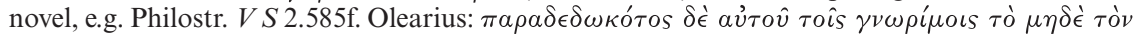

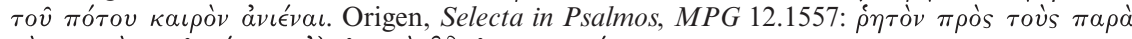

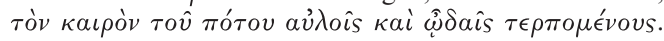




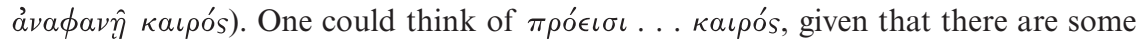

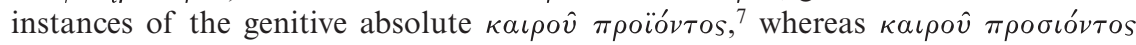
appears only in the example of Libanius quoted above. Still, the idea of progression

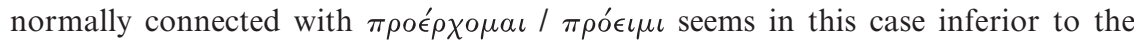
idea of addition expressed by $\pi \rho о \sigma \epsilon ́ р \chi о \mu \alpha \iota / \pi \rho o ́ \sigma \epsilon \iota \mu \iota$. Thus the symposium is marked as a distinctive part of the robbers' banquet, setting the scene for the narration of Chrysion. There remains the kai deleted by the earlier editors and replaced by Papanikolaou. I retain it—like Hägg — as an adverb (too). This would imply an asyndetic construction, which is not very surprising in Xenophon (cf. for example 3.11.5).

University of Bern

STEFAN TILG stefan.tilg@kps.unibe.ch doi:10.1017/S0009838806000759

${ }^{7}$ A look at $T L G$ shows, however, that most of them date from very late or Byzantine authors. The only example before the fourth century A.D. is Origen, Fragmenta in Evangelium Joannis 128.

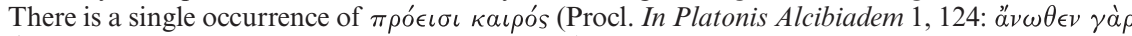

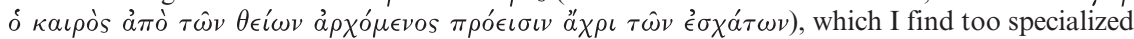
to be convincing.

\section{A GREEK MISCELLANIST AS A LIBIDINOUS THESSALIAN WITCH? PAMPHILE IN APULEIUS' METAMORPHOSES 2-3*}

Among the significant 'speaking' names in Apuleius' Metamorphoses is that of Pamphile, Lucius' hostess who possesses not only an enormous taste for young lovers, but also a considerable knowledge of witchcraft. It is her transformation into a bird in Book 3 of the novel that leads to Lucius' disastrous decision to try out the magic arts himself, with the well-known consequence of his metamorphosis into an ass.

The name Pamphile - the all-lover - certainly wholly accords with the character's behaviour and could therefore be explained as one of the many speaking names within the course of the novel: ${ }^{1}$ Lucius is warned explicitly by Byrrhaena, an old family friend, of Pamphile's infamous sexual appetite: nam simul quemque conspexerit speciosae formae iuuenem, uenustate eius sumitur et ilico in eum et oculum et animum detorquet (Apul. Met. 2.5).

Clearly this explanation for the name Pamphile works perfectly on the level of the narration itself. But one may wonder if Apuleius has chosen the name also for another, that is literary reason. We know that throughout the novel he either mentions

* I am especially grateful to Katerina Oikonomopoulou (Oxford) with whom I discussed the idea of this paper and who gave me a number of helpful comments and to Stephen Harrison (Oxford) who read a draft version of this paper.

${ }^{1}$ See B. Hijmans, Jr, 'Significant names and their function in Apuleius' Metamorphoses', in B. L. Hijmans, Jr and R.Th. van der Paardt (edd.), Aspects of Apuleius' Golden Ass (Groningen, 1978), 107-22, esp. 109-10. W. Keulen, 'Significant names in Apuleius: a "good contriver" and his rival in the cheese trade (Met. 1, 5)', Mnemos. 53 (2000), 310-21. 